\title{
Pengaruh Penggunaan Media Tiga Dimensi Terhadap Kemampuan Berpikir Analisis Siswa Pembelajaran Tematik
}

\author{
Efinda Sari *1, Sumarno², Anggun Dwi Setya Putri³
}

1,2,3 Pendidikan Guru Sekolah Dasar, Univesitas PGRI Semarang

\author{
A R T I C L E I N F O \\ Article history: \\ Received 10 February \\ 2019 \\ Received in revised form \\ 09 March 2019 \\ Accepted 15 April 2019 \\ Available online 25 May \\ 2019 \\ Kata Kunci: \\ Media tiga dimensi; \\ Kemampuan analisis; \\ Pembelajaran tematik \\ Keywords: \\ Three dimensional media, \\ analytical skills, thematic \\ learning
}

\begin{abstract}
A B S T R A K
Latar belakang penelitian ini yaitu pembelajaran tematik pada kelas $\mathrm{V}$ masih menggunakan media pembelajaran berupa gambar yang ada pada buku paket. Tujuan dari penelitian adalah mengetahui pengaruh penggunaan media tiga dimensi terhadap kemampuan analisis siswa. Jenis penelitian ini adalah penelitian kuantitatif dalam bentuk PreEksperimental Design dengan jenis One Group Pretest-Posttest. Populasi penelitian ini adalah siswa kelas $\mathrm{V}$ yang berjumlah 27 siswa. Pengumpulan data menggunakan metode tes, observasi, dan dokumentasi. Hasil nilai kemampuan berpikir analisis siswa sebelum dan setelah diberi perlakuan menggunakan media tiga dimensi mengalami peningkatan. Berdasarkan hasil uji-t dketahui thitung 21,649> tabel 1,706. Kesimpulannya media tiga dimensi berpengaruh posistif dan signifikan terhadap kemampuan berpikir analisis siswa.
\end{abstract}

\section{A B S T R A C T}

The background of this research is thematic learning in class $V$ still using learning media that contains images in the book package. The purpose of the study was to understand the use of threedimensional media on students' analytical skills. This type of research is quantitative research in the form of Pre Experimental Design with the type of Pretest-Posttest One Group. The population of this study was fifth grade students who gathered 27 students. Data collection uses test, observation, and documentation methods. The results of the assessment of students' thinking analysis before and after being given permission to use three-dimensional media need to be improved. Based on the results of the t-test know tcount 21.649>t table 1.706. The media conclusions are three positive and significant dimensions of students' analytical thinking abilities.

\section{Pendahuluan}

Pendidikan merupakan suatu proses yang diperlukan untuk mendapatkan keseimbangan dan kesempurnaan dalam perkembangan individu maupun masyarakat. Penekanan pendidikan dibanding dengan pengajaran terletak pada pembentukan kesadaran dan kepribadian individu atau masyarakat di samping transfer ilmu dan keahlian. Dengan proses semacam ini suatu bangsa atau negara dapat mewariskan nilai-nilai keagamaan, kebudayaan, pemikiran dan keahlian kepada generasi berikutnya, sehingga mereka betul-betul siap menyongsong masa depan kehidupan bangsa dan negara yang lebih cerah. Pendidikan juga merupakan sebuah aktifitas yang memiliki maksud atau tujuan tertentu yang diarahkan untuk mengembangkan potensi yang dimiliki manusia baik sebagai manusia ataupun sebagai masyarakat dengan sepenuhnya (Nurkholis, 2013).

Pembelajaran (instruction) adalah perpaduan dari dua aktivitas, yaitu aktivitas belajar (learning) dan aktivitas mengajar (teaching). Aktivitas belajar secara metodologi cenderung lebih dominan pada siswa, sementara mengajar secara intruksional dilakukan oleh guru. Pembelajaran bertujuan untuk

Copyright (C) Universitas Pendidikan Ganesha. All rights reserved. 
mengembangkan seluruh kemampuan dan potensi siswa untuk memenuhi tuntutan kebutuhan zaman dan mempunyai daya saing dalam mempertahankan kehidupannya di era global. Daya saing di era global menuntut siswa mempunyai kemampuan berpikir, pemecahan masalah, dan pembuat keputusan (Silva, 2009). Siswa dituntut untuk memiliki kemampuan berpikir tingkat tinggi untuk memecahkan masalah yang berkaitan dengan isu lokal dan global melalui kegiatan pembelajaran salah satunya yaitu kemampuan berpikir analisis (Osman, K. \& Hiong, L.C., \& Vebrianto, 2013).

Berdasarkan hasil observasi yang dilaksanakan di SDN Tambakrejo 01 Semarang pada tanggal 24 September 2018, bahwa dalam pelaksanaan pembelajaran tematik tema 7 peristiwa dalam kehidupan guru hanya menggunakan gambar yang ada pada buku paket dan menugaskan siswa untuk mengerjakan soal-soal latihan dari LKS. Hal tersebut membuat pemahaman yang diperoleh siswa masih bersifat abstrak. Implikasi dari hal tersebut siswa kurang aktif dalam mengikuti pembelajaran. Selama proses pembelajaran berlangsung, sering dijumpai adanya kecenderungan siswa yang enggan bertanya kepada guru meskipun mereka sebenarnya belum mengerti tentang materi yang disampaikan guru. Siswa menjawab pertanyaan guru yang bersifat analistik hanya dengan cara mengutip dari buku atau bahan pustaka lain tanpa mengemukakan pendapat atau analisisnya terkait dengan pertanyaan yang diberikan guru. Selain itu kondisi kelas masih kurang aktif ketika proses pembelajaran, guru menerangkan dan siswa hanya duduk mendengarkan, mencatat sehingga dalam pembelajaran tersebut guru yang paling dominan aktif dalam proses pembelajaran. Akibat kondisi proses pembelajaran tersebut siswa cenderung merasa jenuh dan bosan, sehingga siswa kurang fokus terhadap materi yang diterangkan oleh guru. Sikap pasif siswa ini salah satunya disebabkan pola pembelajaran yang membiasakan siswa untuk menerima bukan mencari. Siswa hanya menghafal sehingga pemahaman mereka akan materi kurang.

Upaya guru mengatasi permasalahan di atas, yaitu dengan melakukan banyak cara dalam kegiatan belajar mengajar. Guru melaksanakan pembelajaran tematik di sekolah dapat memilih dan menggunakan media pembelajaran yang dapat melibatkan siswa aktif dalam belajar, baik secara fisik maupun mental sehingga materi yang diajarkan oleh guru menjadi lebih konkrit dan siswa akan mengingatnya dalam jangka waktu yang lama. Selain itu, kemampuan mengaitkan pada pembelajaran tematik membutuhkan kemampuan berpikir analisis. Pembelajaran model ini akan lebih menarik dan bermakna bagi anak karena model pembelajaran ini menyajikan tema-tema pembelajaran yang lebih aktual dan kontekstual dalam kehidupan sehari-hari.

(Herdian, 2010) menyatakan kemampuan analisis adalah kemampuan siswa untuk menguraikan atau memisahkan suatu hal ke dalam bagian-bagiannya dan dapat mencari keterkaitan antara bagianbagian tersebut. Hal tersebut ini juga diperkuat oleh Bloom yang menyatakan bahwa kemampuan berpikir analisis menekankan pada pemecahan materi ke dalam bagian-bagian yang lebih khusus atau kecil dan mendeteksi hubungan-hubungan dan bagian-bagian tersebut dan bagian-bagian itu diorganisir.

Colin Rose Malcom J. Nicholl (2002: 254 dalam Herdian, 2010) kemampuan berpikir analisis dapat ditinjau dari berpikir analisis dalam pemecahan masalah yaitu mendefinisikan secara pasti apa masalah yang sebenarnya, memiliki banyak gagasan, menyingkirkan alternatif yang paling kurang efisien dan membuang pilihan-pilihan yang tidak memenuhi kriteria yang telah ditetapkan sebelumnya, menentukan pilihan (opsi) ideal dengan melihat solusi terbaik yang memenuhi kriteria yang ditetapkan, mengetahui akibat dan dampak dalam menyelesaikan masalah.

Berdasarkan pengertian di atas, kemampuan berpikir analisis adalah kemampuan siswa untuk menguraikan atau memisahkan suatu hal ke dalam bagian-bagiannya dan dapat mencari keterkaitan antara bagian-bagian tersebut. Menganalisis adalah kemampuan memisahkan materi (informasi) ke dalam bagian-bagiannya yang perlu mencari hubungan antara bagian-bagiannya, mampu melihat (mengenal) komponen-komponennya, bagaimana komponen-komponen itu berhubungan dan terorganisasikan, membedakan fakta dari khayalan.

Kata media berasal dari bahasa latin dan merupakan betuk jamak dari kata "Medium" yang secara harfiah berarti perantara atau pengantar. Media pembelajaran adalah segala sesuatu yang dapat digunakan untuk menyalurkan pesan dari pengirim ke penerima sehingga dapat merangsang pikiran, perasaan, perhatian, dan minat serta perhatian sedemikian rupa sehingga proses belajar terjadi (Sadiman, 2002: 6).

Terbatasnya media yang dipergunakan dalam kelas diduga merupakan salah satu penyebab lemahnya mutu belajar siswa. Dengan demikian penggunaan media dalam pengajaran di kelas merupakan sebuah kebutuhan yang tidak dapat diabaikan. Hal ini dapat dipahami mengingat proses belajar yang dialami siswa tertumpu pada berbagai kegiatan menambah ilmu dan wawasan untuk bekal hidup di masa sekarang dan masa akan datang. Salah satu upaya yang harus ditempuh adalah bagaimana menciptakan situasi belajar yang memungkinkan terjadinya proses pengalaman belajar pada diri siswa dengan menggerakkan segala sumber belajar dan cara belajar yang efektif dan efisien. Dalam hal ini, media 
pengajaran merupakan salah satu pendukung yang efektif dalam membantu terjadinya proses belajar (Mahnun, 2012).

Pemakaian media pembelajaran dalam proses belajar mengajar dapat membangkitkan minat dan keinginan yang baru, membangkitkan motivasi dan rangsangan kegiatan belajar, dan bahkan membawa pengaruh-pengaruh psikologis terhadap pebelajar. Penggunaan media pembelajaran pada tahap orientasi pengajaran akan sangat membantu keefektifan proses pembelajaran dan penyampaian pesan dan isi pelajaran pada saat itu (Wiratmojo, P dan Sasonohardjo, 2002 dalam Falahudin, 2014). Sebagai salah satu komponen pembelajaran, media tidak bisa luput dari pembahasan sistem pembelajaran secara menyeluruh. Pemanfaatan media seharusnya merupakan bagian yang harus mendapat perhatian pembelajar dalam setiap kegiatan pembelajaran. Namun kenyataanya bagian inilah yang masih sering terabaikan dengan berbagai alasan. Alasan yang sering muncul antara lain: terbatasnya waktu untuk membuat persiapan mengajar, sulitnya mencari media yang tepat, dan tidak tersedianya biaya. Hal ini sebenarnya tidak perlu terjadi jika setiap pembelajar telah membekali diri dengan pengetahuan dan keterampilan dalam hal media pembelajaran.

Media pembelajaran sebagai komponen strategi pembelajaran merupakan wadah dari pesan yang oleh sumber atau penyaluran ingin diteruskan kepada sasaran atau menerima pesan pembelajaran, dan bahwa tujuan yang ingin dicapai adalah terjadinya proses belajar. Media mencakup semua sumber yang diperlukan untuk melakukan komunikasi dengan peserta didik (Trianto, 2014: 227).

Media yang digunakan dalam penelitian ini adalah media tiga dimensi. Media tiga dimensi adalah sekelompok media tanpa proyeksi yang penyajiannya secara visual tiga dimensional. Kelompok media ini dapat berwujud sebagai benda asli baik hidup maupun mati, dan dapat pula berwujud sebagai tiruan yang mewakili aslinya. Benda asli ketika akan difungsikan sebagai media pembelajaran dapat dibawa langsung ke kelas, atau siswa sekelas dikerahkan langsung ke dunia sesungguhnya di mana benda asli itu berada. Apabila benda aslinya sulit untuk dibawa ke kelas atau kelas tidak memungkinkan dihadapkan langsung ke tempat dimana benda itu berada, maka benda tiruannya dapat pula berfungsi sebagai media pembelajaran yang efekt(Daryanto, 2010: 29).

Menurut (Oktavia Dwi, 2012) kegiatan pembelajaran dengan penggunaan media gambar tiga dimensi sebagai sumber belajar menunjukkan adanya peningkatan dalam aktivitas guru atau keterlaksanaan pembelajaran dan hasil belajar siswa. Hal ini sejalan dengan pnelitian yang dilakukan oleh (Septian; Ariski; Jintar Tampubolon, 2015) yang menemukan bahwa mengajarkan materi Menggambar dengan perangkat Lunak akan lebih baik menggunakan media Tiga Dimensi dibandingkan dengan menggunakan media pembelajaran Konvensional.

(Jonkenedi., 2017) menyatakan bahwa Media tiga dimensi dapat digunakan oleh guru dalam pembelajaran yang bisa dibawa benda asli, tiruan atau miniaturnya ke dalam kelas agar proses pembelajaran semakin aktif dan menyenangkan. Selain itu, pembelajaran dengan menggunakan media tiga dimensi akan menjadikan proses pembelajaran semakin bervariasi dan tidak membosankan.

Secara umum dapat disimpulkan bahwa media tiga dimensi merupakan sekelompok media yang berwujud benda asli baik hidup maupun benda mati yang dapat digunakan untuk menyalurkan pesan dari pengirim pesan ke peneriman sehingga dapat merangsang pikiran, perasaan, perhatian dan minat siswa sedemikian rupa sehingga terjadi proses belajar.

Dalam bukunya Nana Sudjana yang dikutip Asrotun (2014:17) mengatakan media tiga dimensi memiliki lima model, yakni: model padat (solid model), model penampang (cuteway model), model kerja (working model), model mock-ups dan model diorama. Penggunaan model padat media tiga dimensi pembelajaran tematik memiliki manfaat seperti siswa dapat berinteraksi langsung dengan media sehingga siswa lebih aktif dalam proses pembelajaran dan mampu meningkatkan kemampuan berpikir analisis siswa.

Pembelajaran tematik sebagai model pembelajaran termasuk salah satu tipe/jenis dari pada model pembelajaran terpadu. Istilah pembelajaran tematik pada dasarnya adalah model pembelajaran terpadu menggunakan tema untuk mengaitkan beberapa mata pelajaran sehingga dapat memberikan pengalaman bermakna kepada siswa (Depdiknas, 2006: 5).

Pembelajaran tematik merupakan salah satu model pembelajaran terpadu (integrated instruction) yang merupakan suatu sistem pembelajaran yang memungkinkan siswa, baik secara individu maupun kelompok aktif menggali dan menemukan konsep serta prinsip-prinsip keilmuan secara holistik, bermakna dan otentik. Holistik memiliki pengertian suatu peristiwa yang menjadi perhatian dalam pembelajaran tematik diamati dan dikaji dari beberapa bidang studi sekaligus. Bermakna dalam pembelajaran tematik berarti pengkajian suatu fenomena dari berbagai macam aspek yang nantinya akan memberikan dampak kebermaknaan materi yang dipelajari. Otentik dalam pembelajaran tematik memungkinkan siswa memahami secara langsung konsep dan prinsip yang ingin dipelajari (Majid, 2014: 80,90-91). 
Pembelajaran tematik salah satu pendekatan pembelajaran holistic. Pembelajaran holistic mengandung dua tujuan yaitu menghasilkan pembelajaran bermakna yang memaksimalkan koknitif otak kiri yang dicapai melalui pengembangan keahlian akademis dan teknis, dan pembelajaran yang bermakna menggunakan otak kanan melaui pengembangan sosial dan keterampilan nilai (Glenn, 2009 dalam Widyaningrum, 2013). Elemen utama pembelajaran holistic adalah keterhubungan antara pengalaman dan realitas dan pembelajaran yang harmoni dengan alam (Jafari, et al, 2012 dalam Ain, 2013). Pembelajaran ini cocok dengan karakteristik siswa kelas rendah yang masih dalam tahap operasional konkrit. Dalam proses belajar siswa diarahkan untuk terlibat langsung dengan lingkungan yang ada disekitarnya, dengan cara melihat, meraba, merasa, membau, dan mendengar atau pembelajaran yang melibatkan seluruh panca indera siswa, sehingga pembelajaran lebih bermakna (Ain, 2013)

Pembelajaran tematik lebih menekankan pada keterlibatan siswa dalam proses belajar secara aktif dalam proses pembelajaran, sehingga siswa dapat memperoleh pengalaman langsung dan terlatih untuk dapat menemukan sendiri berbagai pengetahuan yang dipelajarinya. Melalui pengalaman langsung siswa akan memahami konsep-konsep yang mereka pelajari dan menghubungkannya dengan konsep lain yang telah dipahaminya. Teori pembelajaran ini dimotori para tokoh Psikologi Gestalt, termasuk Piaget yang menekankan bahwa pembelajaran haruslah bermakna dan berorientasi pada kebutuhan dan perkembangan anak. Pembelajaran tematik lebih menekankan pada penerapan konsep belajar sambil melakukan sesuatu (learning by doing). Oleh karena itu, guru perlu mengemas atau merancang pengalaman belajar yang akan mempengaruhi kebermaknaan belajar siswa. Pengalaman belajar yang menunjukkan kaitan unsur-unsur konseptual menjadikan proses pembelajaran lebih efektif. Kaitan konseptual antar mata pelajaran yang dipelajari akan membentuk skema, sehingga siswa akan memperoleh keutuhan dan kebulatan pengetahuan. Selain itu, dengan penerapan pembelajaran tematik akan sangat membantu siswa, karena sesuai dengan tahap perkembangannya siswa yang masih melihat segala sesuatu sebagai satu keutuhan (holistik)(Widyaningrum, 2013).

Berdasarkan beberapa pendapat para ahli di atas dapat diartikan bahwa pembelajaran tematik pada kurikulum 2013 merupakan pembelajaran dengan pendekatan tematik integrasi, tema-tema yang ditentukan merupakan tema yang dekat dengan kehidupan keseharian siswa. Tema digunakan sebagai penyatu beberapa mata pelajaran, sehingga tergabung dan membentuk satu kesatuan tema.

(Rusman, 2015: 274), dalam kegiatan pembelajaran tematik perlu juga diperhatikan mengenai optimalisasi penggunaan media pembelajaran yang bervariasi. Tanpa media yang bervariasi maka pelaksanaan pembelajaran tematik tidak akan berjalan dengan efektif. Media pembelajaran harus dijadikan sebagai bagian integral dengan komponen pembelajaran lainnya, dalam arti tidak berdiri sendiri, tetapi saling berhubungan dengan komponen lainnya dalam rangka menciptakan situasi belajar yang bermkna. Beberapa nilai yang dapat dipetik dari penggunaan media dalam kegiatan pembelajaran tematik di antaranya: dapat mengkonkritkan konsep-konsep yang abstrak, menghadirkan objek-objek yang terlalu berbahaya atau sukar didapatkan dalam lingkungan belajar, menampilkan objek yang terlalu besar atau terlalu kecil, dan memperlihatkan gerakan yang terlalu cepat atau lambat. Penggunaan media dalam pelaksanaan pembelajaran tematik dapat divariasikan ke dalam penggunaan media visual, media audio, dan media audio visual.

Media yang digunakan dalam proses pembelajaran dibuat sesederhana mungkin, dengan tujuan agar siswa tidak mengalami kesulitan dalam memahami materi yang akan disampaikan. Walaupun demikian media tiga dimensi sebagai alat dan sumber pengajaran tidak dapat menggantikan guru sepenuhnya yang artinya media tersebut tetap memerlukan guru sebagai fasilitator dalam penyampainnya agar dapat meningkatkan kualitas pengajaran dari pembelajaran tematik.

Penggunaan media tiga dimensi merupakan salah satu metode guru dalam menyampaikan materi atau bahan pembelajaran. Siswa akan lebih mudah menyerap informasi yang diberikan guru karena dengan menggunakan media tiga dimensi siswa dapat melihat langsung benda-benda yang dimaskud.

Pemanfaatan media pembelajaran dikaitkan erat dengan peningkatan kualitas pembelajaran yang diharapkan. Pemanfaatan media pembelajaran oleh guru diharapkan dapat menciptakan pengalaman belajar yang lebih bermakna, memfasilitasi proses interaksi antara siswa dan guru, sesama murid, serta memperkaya pengalaman belajar siswa. Hal ini dipercaya mampu mengubah suasana belajar yang pasif menjadi aktif melalui beragam sumber belajar yang tersedia.

Pengalaman belajar yang dilakukan siswa seperti mengidentifikasi, merinci, menilai informasi penting diharapkan dapat meningkatkan kemampuan berpikir siswa. Kemampuan berpikir analisis siswa perlu diajarkan agar siswa mampu menyelesaikan permasalahan terutama yang berkaitan dengan materi yang diajarkan oleh guru. 


\section{Metode}

Penelitian ini menggunakan metode penelitian eksperimen. Metode eksperimen merupakan bagian dari metode kuantitatif. Dalam penelitian eksperimen ada perlakuan (treatment). Oleh karena itu, metode eksperimen dapat diartikan sebagai metode penelitian yang digunakan untuk mencari data yang diolah adalah data hasil nilai pretest posttest kemampuan berpikir analisis.

Pada penelitian ini penulis menggunakan Pre-Eksperimental Design dengan menggunakan rancangan One-Group Pretest-Postest. Validitas penelitian ini adalah validitas soal uraian. Data dianalisa dengan menggunakan microsoft excel.

\section{Hasil dan Pembahasan}

Hasil nilai pretest sebagai kemampuan awal hasil kemampuan berpikir analisis siswa sebelum diberi perlakuan dan nilai postest sebagai kemampuan akhir siswa dalam hal kemampuan berpikir analisis setelah diberi perlakuan dengan menggunakan media tiga dimensi.

Tabel 1. Data Hasil Nilai Pretest dan Posttest.

\begin{tabular}{cccc}
\hline Jenis Tes & Nilai Tertinggi & Nilai Terendah & Rata-Rata \\
\hline Pretest & 68,57 & 42,86 & 51,64 \\
Posttest & 94,28 & 65,71 & 82,22 \\
\hline
\end{tabular}

Dapat diketahui bahwa hasil belajar sebelum diberi perlakuan nilai pretest menunjukkan rata-rata sebesar 51,64. Sedangkan setelah diberi perlakuan nilai posttest menunjukkan rata-rata sebesar 82,22. Dari hasil nilai pretest dan posttest menunjukkan nilai rata-rata posttest lebih tinggi daripada nilai pretest. Hal tersebut terjadi karena adanya perlakuan dengan menggunakan media tiga dimensi dalam kegiatan belajar mengajar yang dilakukan pada saat penelitian. Sehingga terdapat peningkatan kemampuan berpikir analisis siswa kelas $\mathrm{V}$.

Sebelum melakukan pengujian hipotesis perlu dilakukan uji persyaratan analisis data terlebih dahulu. Pada uji persyaratan data ini dilakukan pengujian data sebelum perlakuan dan sesudah perlakuan dengan menggunakan uji normalitas. Uji normalitas terdiri dari uji normalitas awal (sebelum diberikan perlakuan) dan uji normalitas akhir (setelah diberikan perlakuan menggunakan media tiga dimensi). Uji normalitas yang digunakan ini bertujuan untuk mengetahui apakah hasil nilai pretest dan hasil nilai posttest siswa berasal dari data yang berdistribusi normal atau tidak. Uji normalitas data dilakukan dengan menggunakan uji Lilliefors.

Tabel 2. Uji Normalitas Awal dan Uji Normalitas Akhir

\begin{tabular}{cccc}
\hline Jenis Tes & $\mathrm{L}_{0}$ & Ltabel & Keterangan \\
\hline Normalitas Awal & 0,1349 & 0,173 & Berdistribusi Normal \\
Normalitas Akhir & 0,0933 & 0,173 & Berdistribusi Normal \\
\hline
\end{tabular}

Uji normalitas awal digunakan untuk mengetahui apakah nilai pretest berasal dari sampel yang berdistribusi normal atau tidak. Uji normalitas menggunakan rumus Lilliefors dengan ketentuan bahwa kelompok berdistribusi normal jika memenuhi kriteria $\mathrm{L}_{0}<$ Ltabel yang diukur pada taraf signifikan 0,05. Untuk melakukan uji normalitas data hasil pretest, maka perlu ditentukan nilai Lhitung yang diambil dari nilai terbesar. Hasil perhitungan nilai pretest dengan jumlah $\mathrm{n}$ sebanyak dua puluh tujuh dan taraf 
signifikan 0,05 di peroleh $\mathrm{L}_{\text {tabel }}$ sebesar 0,173 dan $\mathrm{L}_{0}$ atau Lhitung sebesar 0,1349. Karena $\mathrm{L}_{0}<\mathrm{L}_{\text {tabel }}$ yaitu $0,1349<0,173$ maka H0 diterima. Jadi dapat disimpulkan bahwa artinya sampel berdistribusi normal.

Uji normalitas akhir digunakan untuk mengetahui apakah nilai posttest berasal dari sampel yang berdistribusi normal atau tidak. Uji normalitas menggunakan rumus Lilliefors dengan ketentuan bahwa kelompok berdistribusi normal jika memenuhi kriteria $\mathrm{L}_{0}<$ Ltabel yang diukur pada taraf signifikan 0,05. Hasil perhitungan nilai posttest dengan jumlah $\mathrm{n}$ sebanyak dua puluh tujuh dan taraf signifikan 0,05 diperoleh $\mathrm{L}_{\text {tabel }}$ sebesar 0,173 dan $\mathrm{L}_{0}$ atau Lhitung sebesar 0,0933. Karena $\mathrm{L}_{0}<\mathrm{L}_{\text {tabel }}$ yaitu 0,0933 0,173 maka $\mathrm{HO}$ diterima. Jadi dapat disimpulkan bahwa artinya sampel berdistribusi normal.

Berdasarkan hasil perhitungan menggunakan microsoft excel pada uji normalitas awal dan uji normalitas akhir menunjukkan bahwa hasil nilai pretest dan posttest siswa mengenai kemampuan berpikir analisis siswa pada pembelajaran tematik berasal dari data yang berdistribusi normal. Kemudian langkah selanjutnya yang dilakukan yaitu pengujian hipotesis menggunakan uji t.

Pengujian hipotesis dilakukan untuk mengetahui adanya perbedaan kemampuan akhir siswa dalam hal kemampuan berpikir analisis antara sebelum diberi perlakuan dan kemampuan akhir siswa setelah diberi perlakuan berupa perlakuan menggunakan media tiga dimensi yang dapat dilihat dari hasil nilai pretest dan posttest siswa. Penelitian ini bertujuan untuk mengetahui pengaruh, maka terlebih dahulu merumuskan hipotesis nihil $\left(\mathrm{H}_{0}\right)$ dan hipotesis alternative $\left(\mathrm{H}_{\mathrm{a}}\right)$. Hasil nya menunjukkan bahwa thitung $21,649>$ tabel 1,706 dengan taraf signifikan $(\alpha)=0,05$ dengan $\mathrm{db} 26$. Hal ini berarti ada perbedaan yang signifikan antara hasiil pretest dan hasil posttest.

Taraf signifikansi $(\alpha)$ yang digunakan pada pengujian hipotesis ini yaitu 5\%, sedangkan uji statistik yang digunakan adalah dengan menggunakan Uji-t . Kriteria penolakan hipotesis nol adalah jika nilai thitung (th) lebih besar dari ttabel (tt) pada taraf signifikansi $(\alpha)$ 5\%, maka hipotesis nol ditolak (rata-rata nilai kemampuan berpikir analisis siswa sebelum dan sesudah perlakuan tidak sama) media tiga dimensi berpengaruh positif terhadap kemampuan berpikir analisis siswa kelas V.

Penggunaan media tiga dimensi berpengaruh kemampuan berpikir analisis siswa. Pada saat di kelas, siswa yang diajar menggunakan media tiga dimensi lebih antusias dalam mengikuti pelajaran daripada siswa yang diajar tanpa menggunakan media tiga dimensi. Hasil nilai pretset posttest kemampuan berpikir analisis siswa yang diajar menggunakan media tiga dimensi, hasilnya lebih baik daripada siswa yang diajar tanpa menggunakan media tiga dimensi. Hal ini dikarenakan media tiga dimensi akan memudahkan guru maupun siswa dalam melakukan pengamatan serta praktek yang berkaitan dengan pembelajaran tematik secara konkret sehingga kemampuan berpikir analisis siswa dapat meningkat.

Dengan demikian hipotesis alternatif bisa diterima. Berdasarkan penghitungan uji-t diperoleh kesimpulan bahwa terdapat perbedaan yang signifikan kemampuan berpikir analisis siswa kelas $\mathrm{V}$ antara nilai pretest (sebelum dilakukan perlakuan) dengan nilai posttest (setelah dilakukan perlakuan).

Tabel 3. Uji-t Pretest Posttest

\begin{tabular}{ccc}
\hline Aspek & thitung & $t_{\text {tabel }}$ \\
\hline Kemampuan Berpikir Analisis & 21,649 & 1,706 \\
\hline
\end{tabular}

Dari hasil perhitungan diperoleh bahwa $t_{\text {hitung }}=21,649$. Kemudian dibandingkan dengan harga $t_{\text {tabel }}$ pada $\mathrm{db}=26$ dan taraf signifikansi $=0,05(5 \%)$ didapatkan $t_{\text {tabel }}$ sebesar 1,706 . Karena $t_{\text {hitung }}>t_{\text {tabel }}$ yaitu 21,649 > 1,706 maka $\mathrm{H}_{0}$ ditolak dan $\mathrm{H}_{\mathrm{a}}$ diterima. Hal ini dapat disimpulkan bahwa $\mathrm{H}_{0}$ ditolak (rata-rata nilai membaca intensif siswa sebelum dan sesudah perlakuan tidak sama) media tiga dimensi berpengaruh positif terhadap kemampuan berpikir analisis siswa kelas V.

Hasil uji gain pretest posttet kemampuan berpikir analisis siswa, diperoleh bahwa kemampuan berpikir analisis siswa memperoleh nilai gain rata-rata sebesar 0,64 dengan kriteria sedang.

\section{Simpulan dan Saran}

Berdasarkan hasil analisis data dan pembahasan yang telah dilakukan dapat disimpulkan bahwa penggunaan media tiga dimensi berpengaruh terhadap kemampuan berpikir analisis siswa materi peristiwa dalam kehidupan kelas V SDN Tambakrejo 01 Semarang. Adapun saran yang bisa disampaikan 
melaui penelitian ini adalah 1) kepada guru, bisa menggunakan media tiga dimensi dalam pembelajaran tematik untuk meningkatkan berfikir analisi siswa (2) kepada kepala sekolah, diharapkan mampu mengarahkan serta memfasilitasi guru lain guna mengembangkan media pembelajaran serupa, (3) kepada peneliti lain yang memiliki penelitian serupa, bisa menjadikan penelitian ini sebagai referensi ataupun melanjutkan penelitian ini untuk lebih sempurna.

\section{Daftar Rujukan}

Ain, N. (2013). Implementasi Kurikulum KTSP: Pembelajaran Tematik Di Sekolah Dasar. Jurnal Inspirasi Pendidikan Universitas Kanjuruhan Malang.

Daryanto. (2010). Belajar dan Mengajar. Bandung: Yrama Widya.

Depdiknas. (n.d.). Permendikbud No 22 Tahun 2006 Tentang Standar Isi: Sistem Pendidikan Nasional. 2006.

Falahudin, I. (2014). Pemanfaatan Media dalam Pembelajaran. Jurnal Lingkar Widyaiswara, 1(4), 104-117.

Herdian. (2010). Metode Pembelajaran Discovery. Retrieved November 4, 2018, from

http://herdy07.wordpress/2010/05/27/metode-discovery-penemuan.html

Jonkenedi. (2017). Penggunaan Media Tiga Dimensi untuk Meningkatkan Keaktifan Siswa dalam Pembelajaran IPA. Jurnal Pendidikan Guru Sekolah Dasar, 6(6).

Mahnun, N. (2012). Media Pembelajaran (Kajian terhadap Langkah-langkah Pemilihan Media dan Implementasinya dalam Pembelajaran). Jurnal Pemikiran Islam, 37(1), 27-35.

Majid, A. (2014). Pembelajaran Tematik Terpadu. Bandung: Remaja Rosdakarya.

Nurkholis. (2013). Pendidikan Dalam Upaya Memajukan Teknologi. Jurnal Kependidikan, 1(1), 24-44.

Oktavia Dwi. (2012). Penggunaan Media Gambar Tiga Dimensi Untuk Peningkatan Keterampilan Menulis Puisi Bebas Pada Siswa Sekolah Dasar. Jurnal Pgsd Universitas Negeri Surabaya, 1(1).

Osman, K. \& Hiong, L.C., \& Vebrianto, R. (2013). 21st Century Biology An Interdisciplinary Approachof Biology, Technology, Engineering and Mathematics Education. Sosial and Behavioral Sciences, 102, 188-194.

Rusman. (2015). Pembelajaran Tematik Terpadu. Jakarta: Raja Grafindo Persada.

Sadiman, A. S. (2002). Media Pendidikan. Jakarta: PT Raja Grafindo Persada.

Septian; Ariski; Jintar Tampubolon. (2015). Pengaruh Pembelajaran Menggunakan Media Tiga Dimensi

(3D) Terhadap Hasil Belajar Menggambar dengan Perangkat Lunak Kelas XI Program Keahlian Teknik Gambar Bangunan SMK Negeri 2 Meulaboh. Jurnal Educational Building, 1(1).

Silva, E. (2009). Measuring Skills for 21'st-Century Learning. Phi Delta Kappa, 630-634. 
Trianto. (2014). Model Pembelajaran Terpadu. Jakarta: Bumi Aksara.

Widyaningrum, R. (2013). Model Pembelajaran Tematik di MI/SD. Jurnal Jurusan Tarbiyah Stain Ponorogo, 10(1). 